\title{
Involvement of the Innate Immune System in the Pathogenesis of Chronic Obstructive Pulmonary Disease
}

\author{
Stanislav Kotlyarov
}

Department of Nursing, Ryazan State Medical University, 390026 Ryazan, Russia; SKMR1@yandex.ru

\begin{abstract}
Chronic obstructive pulmonary disease (COPD) is a common, socially significant disease characterized by progressive airflow limitation due to chronic inflammation in the bronchi. Although the causes of COPD are considered to be known, the pathogenesis of the disease continues to be a relevant topic of study. Mechanisms of the innate immune system are involved in various links in the pathogenesis of COPD, leading to persistence of chronic inflammation in the bronchi, their bacterial colonization and disruption of lung structure and function. Bronchial epithelial cells, neutrophils, macrophages and other cells are involved in the development and progression of the disease, demonstrating multiple compromised immune mechanisms.
\end{abstract}

Keywords: COPD; innate immune system; inflammation; bronchial epithelium; macrophages; TLR; bacterial colonization

\section{Introduction}

Chronic obstructive pulmonary disease (COPD) is a common, socially significant disCitation: Kotlyarov, S. Involvement of the Innate Immune System in the Pathogenesis of Chronic Obstructive Pulmonary Disease. Int. J. Mol. Sci. 2022, 23, 985. https://doi.org/ 10.3390/ijms23020985

Academic Editors: Alain Couvineau, Hang Thi Thu Nguyen, Jéremy Jéremy Denizot and Elisabeth Billard

Received: 27 December 2021

Accepted: 15 January 2022

Published: 17 January 2022

Publisher's Note: MDPI stays neutral with regard to jurisdictional claims in published maps and institutional affiliations.

Copyright: (C) 2022 by the author. Licensee MDPI, Basel, Switzerland. This article is an open access article distributed under the terms and conditions of the Creative Commons Attribution (CC BY) license (https:// creativecommons.org/licenses/by/ $4.0 /)$. ease [1]. It is one of the leading causes of hospital admissions, disability and mortality [2,3]. The prevalence of the disease shows negative trends in many countries of the world, which is associated with a high prevalence of smoking and exposure to aeropollutants [4]. Moreover, epidemiological data on the prevalence of COPD differ depending on the methods of diagnosis and classification of the disease used [5].

COPD is associated with a significant economic burden on patients and their families, and may also have an impact on the health care system in some countries [6]. This effect is due to the negative impact on work capacity and prognosis, which are related both to the disease itself and to comorbid pathology, which is widespread in patients with COPD. Indeed, cardiovascular disease, osteoporosis and cachexia are often associated with COPD and contribute to the overall clinical picture.

COPD is a chronic disease, the leading cause of which is associated with the long-term inhalation of components of tobacco smoke [7]. Chronic inflammation persists for many years, and the subsequent remodeling of the bronchi leads to the development of airway obstruction and increased tissue hypoxia. Hypoxia and systemic inflammation contribute significantly to the development of pulmonary and extrapulmonary clinical heterogeneity of COPD, which influences the natural history of the disease [8,9].

Spirometry is considered to be a key method for diagnosing COPD and should be used more widely in clinical practice $[10,11]$. Spirometry screening improves diagnosis, given that patients may go a long time without seeking medical care, considering respiratory symptoms as a natural manifestation of smoking. In this regard, early diagnosis and cessation of smoking improve the therapeutic effectiveness of patient management. The diagnosis of COPD should be assumed in long-term smokers over 40 years of age who have chronic respiratory symptoms, such as cough with sputum production and shortness of breath [11]. Assessment of respiratory symptoms is an important clinical tool to assess the functional status of COPD patients [12].

Infectious exacerbations of COPD are associated with a worsening of the clinical manifestations of the disease, especially with a high frequency of exacerbations [13]. This 
variant course of COPD is of great clinical interest because the frequency of exacerbations influences the clinical picture and prognosis. Bacterial colonization is an important factor of COPD progression [14]. The normal bronchi are known to be inhabited by a diverse microbial community, which contributes to the regulation of the immune response in the lungs. Increased bacterial load and changes in the type of colonizing bacteria in COPD are associated with increased inflammation in the airways and a more rapid decline in forced expiratory volume in the first second $\left(\mathrm{FEV}_{1}\right)[15,16]$.

There is increasing evidence that dysregulation of the innate immune system is associated with the development and progression of COPD. Research in recent years has significantly expanded our understanding of the mechanisms available to the innate immune system to protect the organism. Inflammation in the bronchi involves many cells, which demonstrate complex cross-linkages in the innate immune response. The role of macrophages in inflammation in COPD has been the subject of numerous studies that have expanded the understanding of their involvement in immune mechanisms.

The aim of this review is to discuss the role of the innate immune system in the development of COPD and how impaired innate immune system mechanisms are associated with the clinical heterogeneity of COPD.

\section{The Innate Immune System}

The innate immune system is an evolutionarily ancient defense system that allows the organism to maintain constancy of its macromolecular composition by detecting and removing foreign molecules and providing resistance to infectious agents [17]. Given that large volumes of inhaled air containing various aeropollutants and microorganisms pass through the lungs on a daily basis, this organ requires serious immune protection.

The innate immune system uses many cellular and humoral mechanisms [18]. The innate immune system is thought to react nonspecifically to different agents. The consequence of this can be damage to one's own cells. In addition, micro-organisms have developed a wide range of strategies that are used to colonize the bronchi [19]. Recent evidence suggests that some mechanisms of the innate immune system allow the formation of immunological memory [20], highlighting the complexity and underestimation of this part of the immune system.

Cigarette smoke contains a significant number of different components, including free radicals and reactive oxygen species involved in lipid peroxidation [21]. Exposure to components of cigarette smoke can affect immune processes, leading not only to impaired infectious lung protection, but also to chronic inflammation and related resulting effects on tissue structure and function.

Thus, the role of the innate immune system in chronic diseases such as COPD and atherosclerosis is the focus of increased attention.

\subsection{The Innate Immune Function of Airway Epithelial Cells}

Respiratory epithelial cells are exposed to many different inhaled particles and gases every day. These cells form a barrier between the external and internal environment of the body and play a key role in organizing inflammatory and immune responses in the lungs [22]. The accumulated knowledge has expanded the understanding of the role of respiratory epithelium in the innate immune system of the lungs [23]. The function of the epithelium in protecting the host from infection involves several known mechanisms.

The first line of defense is provided by the barrier function of epithelial cells through dense intercellular junctions and the mechanical clearance of the airways, which is considered a key protective mechanism of the epithelium [24]. Epithelial mucus production and mucociliary clearance are mechanisms that ensure bronchial clearance of inhaled and aspirated particles and pathogens. This function is provided by the production of mucus as well as by the presence of coordinated beating epithelial cell cilia.

Detailed analysis has shown that mucus is not homogeneous in composition and function, but consists of two layers that together form the airway surface liquid [25]. The 
first layer is the layer of periciliary liquid. The periciliary liquid has a low viscosity which enables the cilia to beat rapidly (about 8-15 Hz) [25]. This layer is important for normal mucociliary clearance, as the co-ordinated beating of the cilia ensures the transport of the overlying mucus layer where inhaled substances and pathogens are retained [26]. The second layer is represented by epithelial mucus, which consists mainly of water, but also mucins, proteins, lipids, salts and other molecules. Epithelial mucus acts as a physical barrier for many pathogens $[27,28]$. Mucins, through their side chains, are able to bind to a variety of particles that reach the epithelium and can remove them from the respiratory tract through the mechanism of mucociliary clearance $[27,29,30]$.

In COPD, these mechanisms may be impaired, accompanied by mucus hypersecretion. Mucus hypersecretion is associated with mucins, of which MUC5AC is considered the most important [31,32]. MUC5AC is produced predominantly by goblet cells of the bronchial epithelium [33]. Overproduction of MUC5AC in COPD leads to increased airway obstruction by mucus [31]. Elevated concentrations of MUC5AC in the airways may contribute to the development and progression of COPD and are associated with clinical manifestations of the disease, including declines $\mathrm{FEV}_{1}$ and increased risk of exacerbations [34]. Increased sputum production is thought to be one of the clinical characteristics of the bronchial phenotype of COPD. In addition to affecting the quantitative and qualitative parameters of mucus, exposure to cigarette smoke reduces cilia length, which also reduces the efficiency of mucociliary clearance [35].

In addition to the first line of defense of the epithelium, which is provided by the mechanical cleansing of the respiratory tract, another important mechanism is considered to be chemical and immune defense through the production of certain molecules [25]. These substances belong to different chemical groups and are involved in the regulation of the immune response.

Antimicrobial peptides such as defensins and cathelicidins play an important role in the protective function that bronchial epithelial cells provide [26,36,37]. Defensins have antimicrobial activity, affecting membrane permeability in bacteria and fungi [38-40]. They also exhibit a number of antiviral effects, including a direct effect on viral envelopes, capsids and glycoproteins. They have also been found to inhibit the entry of some viruses into cells and their ability to prevent viral replication [41]. These findings are consistent with the fact that defensin expression in the respiratory epithelium is increased by exposure to pathogenic bacteria or viruses $[26,42,43]$.

Elevated levels of $\beta$-defensin-1 protein may be considered a marker of COPD [44]. Sputum beta-defensin- 1 has a negative correlation with $\mathrm{FEV}_{1}$ [45]. Furthermore, primary human bronchial epithelial cells in patients with COPD produce higher levels of beta-defensin-1 than epithelial cells from healthy donors when infected with nontypeable Haemophilus influenza (NTHi) in an in vitro experiment [45]. Expression of human beta-defensin-2 (hBD-2) was shown to be elevated in the distal airways of patients with COPD [46]. Moreover, hBD-2 mRNA levels correlated positively with interleukin-8 (IL-8) mRNA levels, and correlated negatively with predicted values of $\mathrm{FEV}_{1}$ and $\mathrm{FEV}_{1} / \mathrm{FVC}$ (forced vital capacity) [46]. In another study, smoking was associated with a significant reduction in hBD-2 levels in sputum in patients with acute Pseudomonas aeruginosa [37]. Moreover, the release of the proinflammatory cytokine IL-8 from epithelial cells is increased when smoke exposure and bacterial infection are combined. These findings confirm the negative effects of smoking on the protective function of the epithelial barrier.

Another representative of antimicrobial peptides in humans is LL-37, which belongs to the cathelicidin class [26]. LL-37 is induced by inflammatory or infectious stimuli and exhibits antimicrobial activity against Gram-positive and Gram-negative bacteria [47,48]. It also binds and neutralizes lipopolysaccharide (LPS) activity, protecting against endotoxic shock [49]. LL-37 also shows activity against fungi and viruses, can affect apoptosis, and has chemotactic activity for neutrophils, monocytes, mast cells and T cells [50-52]. In addition to its antimicrobial properties, LL-37 may be involved in tissue repair and wound healing [53]. LL-37 production is also induced by short-chain fatty acids, such as butyrate, 
which are produced by gut bacteria, demonstrating the lung-gut axis $[54,55]$. LL-37 exerts its action via several receptors such as formyl peptide receptor 2 (FPR2), epidermal growth factor receptor (EGFR), erb-b2 receptor tyrosine kinase 2 (ErbB2) and purinergic receptor P2X7 (P2X7R) [53,56]. In addition, this peptide can exert its antimicrobial action directly through electrostatic interaction with negatively charged bacterial membranes [53].

Studies suggest that LL-37 may be involved in the pathogenesis of COPD [56]. The increased expression of LL-37 in the airways and lung alveoli in COPD has been found. Because LL-37 can promote IL-8 production and induce apoptosis in bronchial and alveolar epithelial cells, increased levels of LL-37 in the sputum of patients with COPD have been associated with airway obstruction and a worsening of the clinical course of COPD [50]. Another mechanism that is associated with a negative effect on clinical presentation is that LL-37 enhances MUC5AC mucin production in the airways of COPD via the TACETGF- $\alpha$-EGFR pathway [57]. LL-37 levels in sputum have been shown to be higher during exacerbations of COPD induced by NTHi and Moraxella catarrhalis compared to baseline [58]. Interestingly, plasma LL-37 levels were lower in COPD patients at high risk of frequent exacerbations than in normal patients [59]. These data suggest that decreased plasma LL-37 levels may increase the risk of exacerbations in patients with COPD. In this regard, it should be noted that the cathelicidin LL-37 also plays a protective role by affecting barrier function and tight junction proteins in the bronchial epithelium against exposure to cigarette smoke [60].

In addition to antimicrobial peptides, airway epithelial cells are involved in the production of bioactive lipid mediators of inflammation and inflammation resolution [61]. Eicosanoids are synthesized from some polyunsaturated fatty acids, mainly arachidonic acid, which can be released from membrane phospholipids by phospholipase A2. Secretory phospholipase A2 (sPLA2) is secreted from ciliated cells and acts on the goblet cells to induce production of MUC5AC, Leukotriene B4 (LTB4) and Leukotriene C4 (LTC4) [62]. Goblet cells are considered to be effector pro-inflammatory cells in the airways [62].

Arachidonic acid can be converted into eicosanoid mediators by three enzymatic pathways: cyclooxygenase (COX), lipoxygenase (LO) and cytochrome P450 (CYP) [63].

In an experiment on Human Bronchial Epithelial Cells (HBEC) line, the production of mainly prostaglandins (PGE2, PGD2) and epoxides (e.g., 14,15-EET (14,15-epoxy-5Z,8Z,11Zeicosatrienoic acid)) has been shown. However, exposure of cultured cells to IL-13 and IL-4 resulted in a significant increase in 15-Hydroxyeicosatetraenoic acid (15-HETE) production and a moderate increase in 12-HETE concentration and a decrease in PG production [64]. 15-HETE is considered an important participant in inflammation due to its ability to inhibit the migration of inflammatory cells in response to chemotactic factors $[64,65]$. In addition, 15-HETE is involved in lipoxin synthesis and can modulate cell proliferation [66-68].

PGE2 is an eicosanoid derived from arachidonic acid by COX-2. It induces many different effects by acting through four different G-protein coupled receptors (EP1-4) [69]. PGE2 is known as a respiratory smooth muscle relaxant and may also have bronchoprotective properties, promoting cell growth in the bronchial epithelium [62,70-72]. PGE2 also has anti-inflammatory properties via the activation of the EP4 receptor [73].

PGE2 reduces the production of several pro-inflammatory cytokines, such as IL8, IL-12, monocyte chemotactic protein (MCP)-1 and granulocyte-macrophage colonystimulating factor (GM-CSF), which are involved in leukocyte migration [74-77].

Some bacteria use PGE2 to counteract inflammation, which contributes to their colonization of the airways of patients with COPD and may play a role in disease progression [78]. In particular, Streptococcus pneumoniae, M. catarrhalis and NTHi have been shown to induce COX-2 expression and prostaglandin E2 (PGE2) production in the respiratory epithelium [78-80]. It was also shown that in addition to $M$. catarrhalis induced COX-2 expression and increased PGE2 production in lung epithelial cells, EP2 and EP4 receptors were also activated in these cells [78]. Thus, the increased concentration of prostaglandin PGE2 in the lungs of patients may be related to the pathogenesis of COPD [81]. This seems important given the important immunomodulatory function of PGE2 on dendritic cells [82]. 
Nitric oxide (NO) is another biologically active substance that is involved in many physiological and immune processes in the lungs [83]. The role of nitric oxide is well known from the field of vascular biology, where its bioavailability is related to endothelial dysfunction [84]. Most of the exhaled NO is due to constitutive expression of NOS2 [85,86].

In the airway epithelium, NO is involved in the mucociliary function, where it upregulates ciliary beat frequency [87]. NO has also been shown to be involved in the regulation of epithelial ion transport [88] and may also contribute to the restoration of epithelial integrity [89]. In addition, $\mathrm{NO}$ is considered to be a universal player in the immune system [90]. NO modulates inflammation by regulating the production of epithelial inflammatory mediators and also directly contributes to innate immune defense [90]. Levels of $\mathrm{NO}$ can both increase and inhibit NF-kB activation [83]. Immune cells use NO to destroy pathogens, which is an evolutionarily ancient mechanism [91]. NO acts in a non-specific manner, killing various targets, including bacteria, protozoa and viruses [92]. However, due to lack of specificity, this mechanism may also have negative potential and, if not adequately regulated, may lead to concomitant damage to normal cells and tissues [86,93].

Pro-inflammatory cytokines, which are released by mononuclear cells, can stimulate the expression of iNOS [94,95]. NO production by epithelial cells is enhanced in the presence of LPS, interferon gamma, IL-1 $\beta$, TNF- $\alpha$ [96].

Patients with COPD had significantly increased iNOS mRNA and protein levels compared to non-smokers and smokers with normal lung function. In addition, there was a negative correlation between iNOS protein levels and lung function parameters such as $\mathrm{FEV}_{1}$ and $\mathrm{FEV}_{1} / \mathrm{FVC}$ [97].

Airway epithelial cells can be an important source of inflammatory mediators in smoking and COPD, such as IL-1 $\beta$, IL-8, TNF- $\alpha$ and GM-CSF [98,99]. IL-8 is an important mediator of airway inflammation and innate immunity. It is a chemoattractant for neutrophil cells [100]. IL-8 levels are elevated in the induced sputum of patients with COPD $[100,101]$.

Cigarette smoke can increase IL-8 production by bronchial epithelial cells, acting in a concentration- and time-dependent manner. The concentration of IL-8 was higher in proximal airway samples than in distal alveolar samples [98]. The combination of smoke exposure and bacterial infection also increased the release of the proinflammatory cytokine IL-8 from epithelial cells [37]. The cytochrome P450-derived signaling molecules 11,12-EET and 14,15-EET caused a decrease in IL-8 production induced by smoking. Reduced levels of EET may decrease the anti-inflammatory capacity of epithelial cells, representing another mechanism of inflammation regulation [100].

Thus, the bronchial epithelium demonstrates the presence of various tools for initiating and maintaining inflammation, and also has some anti-inflammatory mechanisms. This function of bronchial epithelial cells is related to their ability to detect pathogens and induce a response, through the expression of pattern recognition receptors. The expression and function of TLRs on airway epithelial cells is of increasing interest. Toll-like receptors are evolutionarily ancient pattern recognition receptors of the innate immune system [102]. They recognize pathogen-associated molecular patterns (PAMPs) and trigger innate immune responses involved in the first line of host defense against microbial infection, including cytokine production.

TLR1-6 and TLR9 have been shown to be expressed in human airway epithelial cells, and TLR2 and TLR4 are expressed in alveolar epithelial cells [103-105]. TLR2 is involved in the detection of Gram-positive bacteria, whereas TLR4 recognizes LPS of Gram-negative bacteria [106].

TLR4 expression is increased in patients with mild to moderate COPD compared to normal controls, but TLR4 expression decreased with increasing disease severity and declining $\mathrm{FEV}_{1}$ [107]. Reduced TLR4 expression in the lungs was associated with airflow limitation and emphysema in smokers [108]. In contrast, in another study, TLR4 expression in the bronchial epithelium was increased in severe and very severe stable COPD compared with non-smokers [109]. In addition, NOD1 expression was elevated in the bronchial 
epithelium in severe and very severe stable COPD compared to patients with mild and moderate stable COPD. In this study, the degree of airway obstruction was positively correlated with increased $P$. aeruginosa bacterial load and decreased $H$. influenzae load in bronchial biopsy samples from smokers and patients with stable COPD [109]. These findings are consistent with the role of TLR4 in removing $H$. influenzae and altering the lung microbiological landscape in severe COPD [109]. Differences in TLR4 expression in the bronchial epithelium in different individuals may reflect the morphological and clinical and functional heterogeneity of COPD, including the development of emphysema and exacerbations. It is known that despite a common etiological factor, the clinical course of COPD, including the development of emphysema, the frequency of exacerbations and the rate of progression of airway obstruction may differ between individuals. TLR2 signalling is also crucial for airway mucin expression in Mycoplasma pneumoniae respiratory infection [110].

A crucial feature of the immune function of the bronchial epithelium is the ability to distinguish between harmful pathogens and harmless members of the commensal flora [111]. Gram-positive bacteria have been found to be less able to stimulate cells of the bronchial epithelium, whereas Gram-negative bacteria are readily recognized [103]. These observations correlated with low TLR2 expression and lack of CD36 receptor expression [103]. The above data may indicate that TLR expression levels and coreceptor expression in epithelial cells are a mechanism for regulating the sensitivity of microbial recognition $[103,112]$. This is important, given that the bronchi are not sterile, but have an extensive microbial landscape that is involved in the immunological tone of the lungs.

Impaired epithelial repair in COPD can lead to a hypercoagulable state, as well as intra-alveolar fibrin accumulation and basal membrane destruction [113]. The presence of alveolar fibrin caused by inhibition of fibrinolysis, in turn, contributes to lung dysfunction and an acute inflammatory response [114].

Thus, bronchial epithelial cells have a variety of mechanisms to maintain immunological homeostasis and provide microbial protection (Figure 1). These tools can be impaired by smoking, leading to activation and maintenance of inflammation and changes in the composition of bronchial microflora, which is associated with exacerbations. Factors associated with impaired bronchial epithelial function are implicated in the pathogenesis of COPD, demonstrating involvement in increased sputum production and airway obstruction.

innate immune defense of the bronchial epithelium in normal bronchi

\section{mechanical barrier}

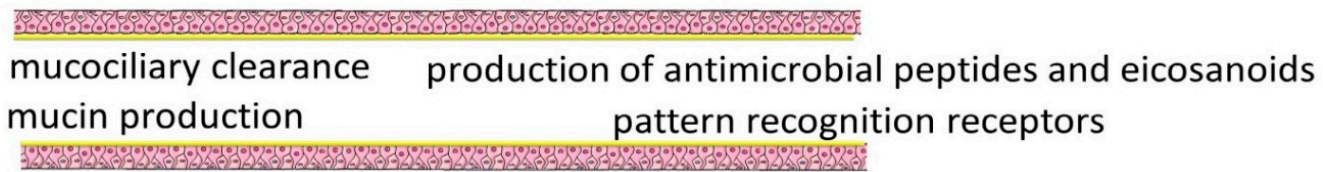

cytokine, chemokine and growth factor production

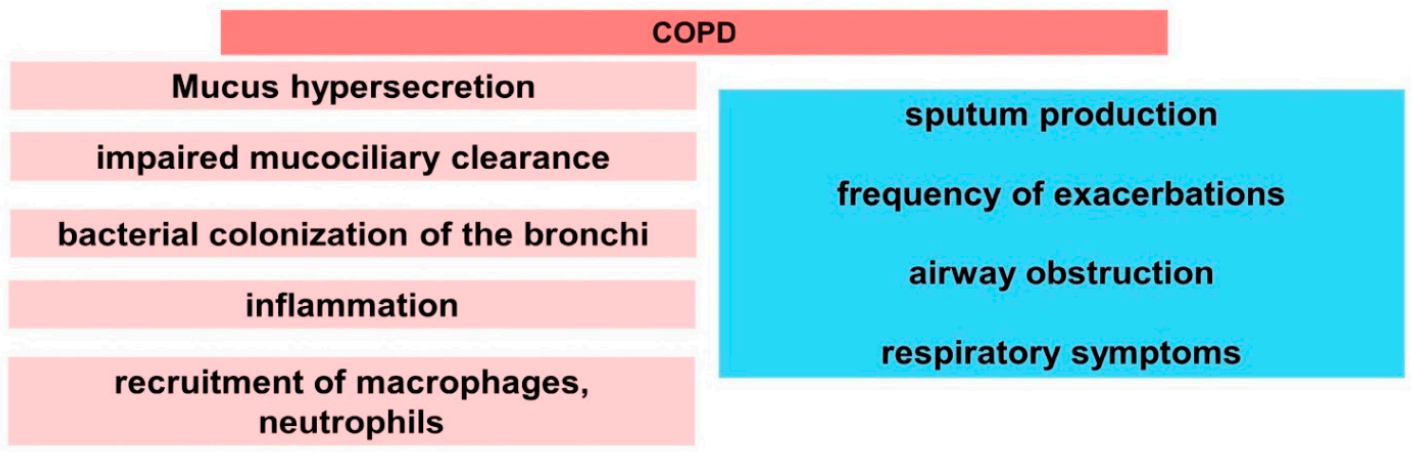

Figure 1. Disruption of innate immune mechanisms of airway epithelial cells in COPD. 


\subsection{Role of Macrophages in the Innate Immune System and Pathogenesis of COPD}

Alveolar macrophages, given their open position in the lumen of the alveoli, are in constant contact with inhaled air and thus with various substances and gases. These cells are considered to be key players in the innate immune defense of the lungs [115]. Macrophages control innate immunity by coordinating inflammatory responses as well as directly phagocytizing pathogens.

The pulmonary macrophage system is characterized by heterogeneity in origin, localization and function. Three main populations of this cell type are known, such as alveolar macrophages, interstitial macrophages and cells differentiated from blood monocytes [116]. The macrophage population in the lungs is maintained both by self-renewal of alveolar macrophages and by differentiation of monocytes recruited from the bloodstream [117].

The ability of alveolar macrophages to self-renew and to maintain an optimal number of macrophages is impaired in COPD. Macrophages are actively involved in inflammation in COPD (Figure 2) [118], as evidenced by data on an increase in their numbers in lung tissue, as well as in sputum and bronchoalveolar lavage fluid [115,119]. Cigarette smoking was associated with a fivefold increase in the number of macrophages in bronchoalveolar lavage [118]. The number of macrophages in the airways correlates with the severity of inflammation, the degree of airflow limitation, and thus with the severity of COPD $[118,120]$. In addition, macrophages are associated with destruction of the alveolar wall in the development of emphysema. Patients with emphysema have been shown to have a significant increase in the number of macrophages in the parenchyma and alveolar space compared to smokers with normal lung function [121]. These findings suggest an important role for macrophages in emphysema. Indeed, in an experimental mouse model of COPD, depletion of macrophages in the lungs led to a reduction in cigarette smoke-induced emphysema, as well as protection against changes in lung function [122].

cigarette smoke, oxidative stress, inflammation

\section{M2 - macrophages M1 - macrophages}

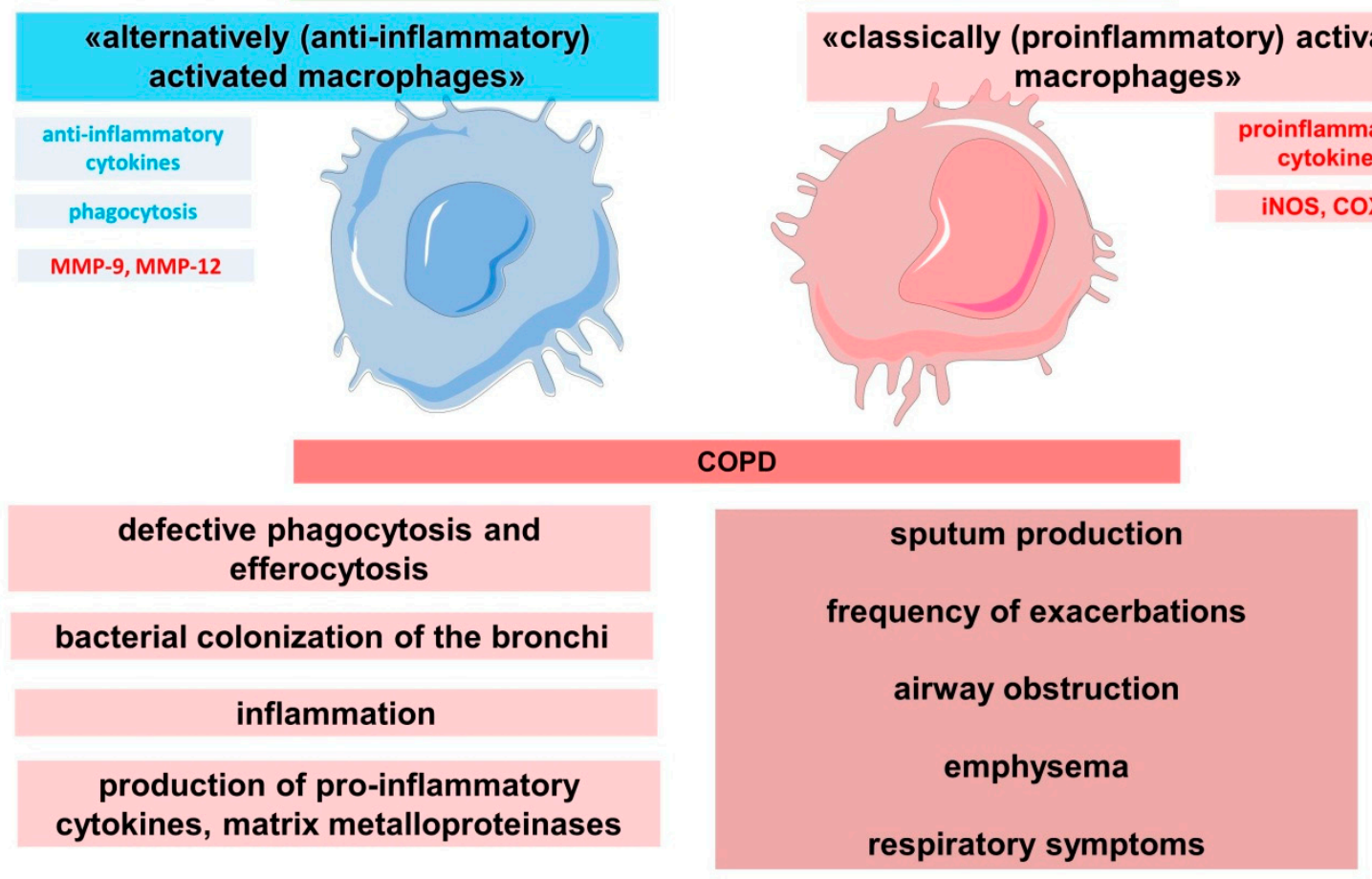

Figure 2. Disruption of innate immune mechanisms of macrophages in COPD. 
The involvement of macrophages in the inflammatory immune response has been the subject of numerous studies. The alveolar macrophage population is not thought to be homogeneous in its involvement in inflammation. According to the classical model, a «classically activated» type 1 (M1) and an «alternatively activated» type 2 (M2) (subtypes M2a, M2b, M2c), and some other types are distinguished [123-125]. M1 macrophages are characterized by pro-inflammatory activity, producing factors such as TNF- $\alpha$, IL- $1 \beta$, IL-6 and IL-12 [126,127]. M1 macrophages also highly express the enzyme cyclooxygenase 2 (COX 2), inducible nitric oxide synthase (iNOS or NOS2) [123,128]. In contrast, M2 macrophages are involved in tissue remodeling, including through stimulation of macrophage efferocytic functions and the production of anti-inflammatory factors such as IL-10 and IL-4 [129,130]. In addition, M0 macrophages that have not been exposed to any pro- or anti-inflammatory stimuli have been identified [131].

Macrophage polarization is based on changes in cell metabolism [128]. Polarization is driven by humoral factors and changes the role of macrophages in the inflammatory process. The role of individual macrophage phenotypes in the pathogenesis of COPD is unclear. While alveolar macrophages were mostly unpolarized in normal lungs, M1 and M2 polarization was significantly increased in smoking and COPD. Co-expression of M1 and M2 polarization markers in the same alveolar macrophage was shown [132].

Although the total number of macrophages in the respiratory tract in smoking and COPD is significantly increased, phagocytosis and elimination of microorganisms and apoptotic cells are impaired, indicating defective functional properties of macrophages [133]. Impaired phagocytosis in COPD is considered an important cause of disease progression [133]. The severity of COPD has been shown to correlate with impaired phagocytosis by alveolar macrophages for nontypeable NTHi and M. catarrhalis [134]. These findings suggest that the inability of alveolar macrophages in COPD to mount an adequate phagocytic response may result in impaired bacterial clearance, which is one of the causes of persistent inflammation [134].

The mechanisms of impaired efferocytosis in patients with COPD are not clear. An accumulation of apoptotic epithelial, endothelial and immune cells in the lungs is noted in patients. In addition, the induction of structural apoptosis of airway cells may be responsible for the development of emphysematous changes.

Macrophages are considered «professional» phagocytes and can regulate the phagocytic activity of epithelial cells [135]. Macrophages express various receptors on the cell surface that are involved in the recognition of molecules or ligands. Phagocytosis is activated when several receptors, such as Fc- and complement receptors, as well as receptors for PAMPs, like TLR, are recognized for antigen recognition, which can make phagocytosis more efficient $[136,137]$. Macrophages express various Toll-like receptors, with TLR1, TLR2, TLR4, TLR5 and TLR6 being expressed on the cell surface and recognizing LPS, lipopeptides and flagellin, whereas TLR3, TLR7, TLR8 and TLR9 are expressed in intracellular compartments (endosomes) and recognize viral DNA and RNA [138]. Importantly, cigarette smoke can stimulate TLR4, thereby enhancing IL-8 production [139].

In addition to TLRs, Nod-like receptor 3 (NLRP3) inflammasome activation may be involved in the pathogenesis of COPD [140,141]. NLRP3 inflamassome is a molecular protein complex that acts as a platform for the maturation of the pro-inflammatory cytokines IL-1 $\beta$ and IL-18, which may contribute to airway inflammation. Inflamassome NLRP3 can be activated in response to a wide range of stimuli, such as PAMPs from invading pathogens and damage-associated molecular patterns (DAMPs) released from dying cells [142]. NLRP3 and IL-1 $\beta$ mRNA are increased in lung tissue in stable COPD and correlate with airway obstruction, but both caspase- 1 and ASC (apoptosis-associated speck-like protein containing a CARD) were largely inactive [143]. It has been suggested that NLRP3 activation of the inflammasome occurs during an infectious exacerbation of COPD [140]. Systemic and local activation of NLRP3 airway inflammation could be considered as a prognostic factor for acute exacerbation of COPD [144]. These findings also suggest the presence of NLRP3 inflammation cross-links, in which different cells, including 
the bronchial epithelium, macrophages and neutrophils, are involved [145-147]. It is shown that neutrophils may play a key role in the activation of NLRP3 inflammasome in alveolar macrophages during respiratory viral infection [148].

Alveolar macrophages in COPD have been shown to develop tolerance to repetitive LPS stimulation, but this only occurs for individual cytokines such as TNF $\alpha$, CCL5 and IL-10. Interestingly, tolerance is not observed for IL-8 and IL-6. IL-8 is a chemoattractant for neutrophils and has higher levels in the lungs of patients with COPD [149]. IL-8 is produced by different cell types, including epithelial cells, macrophages and smooth muscle cells. Bacterial stimulation may be one reason for the increased production of IL-8 in the lungs of patients with COPD, as IL-8 levels in the lungs and neutrophil counts were higher in COPD patients with bacterial colonization $[101,149,150]$. Repeated stimulation of TLR2 or TLR4 causes persistent production of IL-8, which may lead to increased neutrophilic inflammation in the lungs [149]. Experimentation over time showed different patterns between TNF- $\alpha$ and IL-8 gene expression following TLR4 activation, with IL-8 showing slower induction and longer duration of expression [149].

Other important factors contributing to the progression of COPD are enzymes such as matrix metalloproteinases (MMPs) and cathepsins produced by macrophages [151,152]. Their increased production can lead to damage to lung tissue. The overexpression of MMP-1, MMP-2, MMP-7, MMP-9 and MMP-12 has been shown to be associated with the development of emphysema in the lungs of smokers [152-154].

Thus, macrophages are actively involved in the development and progression of COPD, which is related to their impaired function in providing innate immune protection to the lungs.

\subsection{Role of Other Cells in the Regulation of the Innate Immune System and the Pathogenesis of $C O P D$}

Endothelial cells are thought to be involved in the pathogenesis of emphysema. Indeed, observations suggest impaired vascularization of the interalveolar septa in emphysema due to endothelial cell apoptosis [155]. Endothelial cells also demonstrate a role in the innate immune response by participating in the recognition of PAMP and DAMP [156]. Endothelial cells express TLR4 [157]. Interestingly, TLR4 deficiency resulted in spontaneous emphysema in mice in the absence of a significant increase in inflammatory cell numbers and increased endogenous Nox3 activity in endothelial cells [157]. These data highlight the significant role of TLR4 in the maintenance of lung structural integrity and the development of emphysema.

Neutrophils are actively involved in the pathogenesis of COPD, as evidenced by the increased number of activated neutrophils in sputum and bronchoalveolar lavage fluid $[101,158,159]$. The increase in neutrophil counts in bronchial and induced sputum corresponds to an increase in the rate of lung function decline and the severity of COPD disease $[120,160]$. As with macrophages, airway neutrophilia in COPD does not contribute to a reduction in airway colonization and bacterial exacerbations [161-163]. The causes and mechanisms of increased neutrophil migration in COPD are subjects of study. Various cells are involved, including the airway epithelium, leading to increased levels of several neutrophil chemoattractants, including LTB4, IL-8, growth-related oncogene-alpha (GRO $\alpha)$ and epithelial-neutrophil activating peptide (ENA-78 or CXCL5) [164-166].

There is growing interest in phenotypes or subtypes of neutrophil cells that have a wide range of functions in inflammation [162]. These phenotypes involve subpopulations such as the classical pro-inflammatory neutrophil, the pro-angiogenic (reparative) neutrophil, and the anti-inflammatory neutrophil [167]. Consistent with this, neutrophils in the lungs exhibit both pro-inflammatory and anti-inflammatory actions, which are necessary to destroy pathogens and resolve inflammation. They express more than 30 different receptors, including G-protein-coupled receptors, Fc receptors, adhesion receptors, cytokine receptors and pattern recognition receptors [162]. Through the release of serine proteases, such as neutrophil elastase (NE), cathepsin G and proteinase 3 (PR3), neutrophils can cause tissue 
damage [168]. Substrates of neutrophil proteinases include elastin and collagen, which are major components of the extracellular matrix, and their degradation is the morphological basis of COPD progression $[162,169,170]$. However, a negative association has been shown between the number of neutrophils and the degree of alveolar destruction in smokers, in contrast to alveolar macrophages, which requires further research [171].

Dendritic cells play an important role in initiating the immune response [172,173]. The airways contain a rich network of dendritic cells adjacent to epithelial cells, where cells capture antigens and recognize danger signals [172,174]. Dendritic cells are at the intersection of innate immune system connections and adaptive pulmonary immunity. Dendritic cells can produce profibrogenic cytokines, contributing to airway remodeling [175]. They initiate and can regulate immune responses to inhaled antigens, including viruses and bacteria $[174,175]$.

Smokers with COPD have a significantly reduced number of mature dendritic cells in the bronchial epithelium compared to healthy individuals, which may affect the regulation of the immune response and coordination of the innate and adaptive lung immune system $[172,176,177]$.

Thus, the pathogenesis of COPD involves different cells of the innate immune system, which leads to the development of local and systemic inflammation and may be associated with some clinical characteristics of the disease (Figure 3).

smoking

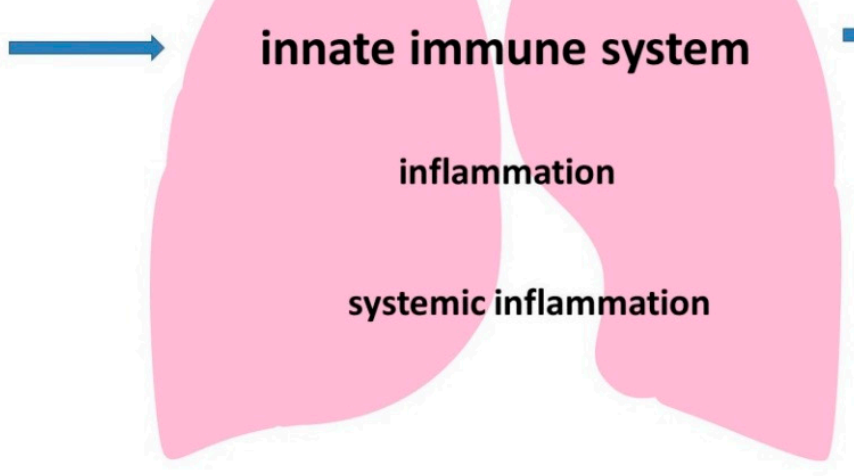

\section{COPD phenotypes}

sputum production

exacerbations

airway obstruction

emphysema

respiratory symptoms

Figure 3. The role of the innate immune system in the development of COPD.

\section{Conclusions}

COPD, due to chronic inflammation of the airways, is characterized by mucus hypersecretion, bronchial remodeling, and emphysema, resulting in reduced lung function and chronic respiratory symptoms.

The lungs, in daily contact with a large number of inhaled aeropollutants and pathogens, have an extensive immune defense provided by the closely linked functions of many cells. This immune defense maintains an optimal balance between localizing normal microflora in the bronchi and detecting and destroying pathogens. Cigarette smoke affects many pathways, disrupting the complex chain of processes that ensure adequate immune control.

The innate immune system has a wide arsenal of tools it uses to detect and eliminate pathogens. That the innate immune system is a serious tool for ensuring an immune response is demonstrated by the fact that invertebrates lacking adaptive immunity have been successful in controlling pathogens. There is also emerging evidence that innate immune cells, including macrophages, are capable of developing immunological memory after previous contact with a pathogen, a characteristic previously thought to be only a 
property of adaptive immunity [178]. Immunological memory is accompanied by epigenetic and metabolic reprogramming of the cells [179]. It involves enhancing the expression of pattern recognition receptors, which increases their sensitivity to certain pathogens, what has been termed "trained immunity" [180,181]. The LPS tolerance previously described can also be considered as an adaptive mechanism of cellular responses to an external stimulus, which results in a lower inflammatory response to repeated stimulation [178,182,183]. Respiratory viral infection with effector CD8 T cells has been shown to induce long-term immune memory in alveolar macrophages [184]. These cells may have sustained trained immunity against bacterial infection in the lungs through rapid induction of chemokines and neutrophilia. The current paradigm of trained immunity involves the formation of a prolonged activation of the innate immune system following exposure to certain stimuli, which can lead to an enhanced immune response to a repeated stimulus [185]. The role of trained immunity has been demonstrated in atherosclerosis, as the resulting enhanced innate immune response is non-specific and can induce prolonged excessive inflammatory responses [186-188]. However, the involvement of these mechanisms in the pathogenesis of COPD remains to be elucidated. Viral infection occurring prior to bacterial exposure has been shown to result in greater host susceptibility to secondary bacterial infection due to the impaired immune response of macrophages and dendritic cells [189]. These findings are of interest given the role of viral infections in the initiation of COPD exacerbations.

Thus, the innate immune system plays an important role in maintaining respiratory immunological homeostasis, but may be significantly impaired by smoking and COPD and contribute significantly to the development and progression of the disease.

Some clinical characteristics of COPD heterogeneity, such as the frequency of exacerbations, the development of emphysema and sputum hyperproduction may be related to some impaired mechanisms of the innate immune system, which is a promising area for future research.

Funding: This research received no external funding.

Institutional Review Board Statement: Not applicable.

Informed Consent Statement: Not applicable.

Data Availability Statement: Not applicable.

Conflicts of Interest: The author declares that they have no conflict of interest.

\section{References}

1. Soriano, J.B.; Kendrick, P.J.; Paulson, K.R.; Gupta, V.; Abrams, E.M.; Adedoyin, R.A.; Adhikari, T.B.; Advani, S.M.; Agrawal, A.; Ahmadian, E.; et al. Prevalence and attributable health burden of chronic respiratory diseases, 1990-2017: A systematic analysis for the Global Burden of Disease Study 2017. Lancet Respir. Med. 2020, 8, 585-596. [CrossRef]

2. Çolak, Y.; Afzal, S.; Nordestgaard, B.G.; Vestbo, J.; Lange, P. Prevalence, Characteristics, and Prognosis of Early Chronic Obstructive Pulmonary Disease. The Copenhagen General Population Study. Am. J. Respir. Crit. Care Med. 2020, 201, 671-680. [CrossRef]

3. Hashemi, S.Y.; Momenabadi, V.; Faramarzi, A.; Kiani, A. Trends in burden of chronic obstructive pulmonary disease in Iran, 1995-2015: Findings from the global burden of disease study. Arch. Public Health 2020, 78, 45. [CrossRef]

4. Blanco, I.; Diego, I.; Bueno, P.; Casas-Maldonado, F.; Miravitlles, M. Geographic distribution of COPD prevalence in the world displayed by Geographic Information System maps. Eur. Respir. J. 2019, 54, 1900610. [CrossRef] [PubMed]

5. Rycroft, C.E.; Heyes, A.; Lanza, L.; Becker, K. Epidemiology of chronic obstructive pulmonary disease: A literature review. Int. J. Chronic Obstr. Pulm. Dis. 2012, 7, 457-494. [CrossRef] [PubMed]

6. Quaderi, S.A.; Hurst, J.R. The unmet global burden of COPD. Glob. Health Epidemiol. Genom. 2018, 3, e4. [CrossRef] [PubMed]

7. Laniado-Laborín, R. Smoking and chronic obstructive pulmonary disease (COPD). Parallel epidemics of the 21 century. Int. J. Environ. Res. Public Health 2009, 6, 209-224. [CrossRef]

8. Tkacova, R. Systemic inflammation in chronic obstructive pulmonary disease: May adipose tissue play a role? Review of the literature and future perspectives. Mediators Inflamm. 2010, 2010, 585989. [CrossRef]

9. Agustí, A.G.N. Systemic Effects of Chronic Obstructive Pulmonary Disease. Proc. Am. Thorac. Soc. 2005, 2, 367-370. [CrossRef] [PubMed]

10. Johns, D.P.; Walters, J.A.E.; Walters, E.H. Diagnosis and early detection of COPD using spirometry. J. Thorac. Dis. 2014, 6, 1557-1569. [CrossRef] 
11. Ruppel, G.L.; Carlin, B.W.; Hart, M.; Doherty, D.E. Office Spirometry in Primary Care for the Diagnosis and Management of COPD: National Lung Health Education Program Update. Respir. Care 2018, 63, 242-252. [CrossRef]

12. Kotlyarov, S.N. Spirometry screening in evaluation of chronic obstructive pulmonary disease at primary care. I.P. Pavlov. Russ. Med. Biol. Her. 2011, 19, 91-95. [CrossRef]

13. Viniol, C.; Vogelmeier, C.F. Exacerbations of COPD. Eur. Respir. Rev. 2018, 27, 170103. [CrossRef]

14. Sethi, S.; Maloney, J.; Grove, L.; Wrona, C.; Berenson, C.S. Airway inflammation and bronchial bacterial colonization in chronic obstructive pulmonary disease. Am. J. Respir. Crit. Care Med. 2006, 173, 991-998. [CrossRef] [PubMed]

15. Hogea, S.-P.; Tudorache, E.; Fildan, A.P.; Fira-Mladinescu, O.; Marc, M.; Oancea, C. Risk factors of chronic obstructive pulmonary disease exacerbations. Clin. Respir. J. 2020, 14, 183-197. [CrossRef]

16. Wilkinson, T.M.; Patel, I.S.; Wilks, M.; Donaldson, G.C.; Wedzicha, J.A. Airway bacterial load and FEV1 decline in patients with chronic obstructive pulmonary disease. Am. J. Respir. Crit. Care Med. 2003, 167, 1090-1095. [CrossRef] [PubMed]

17. Buchmann, K. Evolution of Innate Immunity: Clues from Invertebrates via Fish to Mammals. Front. Immunol. 2014, 5, 459. [CrossRef]

18. Alberts, B.; Johnson, A.; Lewis, J.; Morgan, D.; Raff, M.; Roberts, K.; Walter, P.; Wilson, J.; Hunt, T. Molecular Biology of the Cell, 4th ed.; Garland Science: New York, NY, USA, 2002; Innate Immunity. Available online: https://www.ncbi.nlm.nih.gov/books/ NBK26846/ (accessed on 26 December 2021).

19. Kotlyarov, S.; Kotlyarova, A. Molecular Mechanisms of Lipid Metabolism Disorders in Infectious Exacerbations of Chronic Obstructive Pulmonary Disease. Int. J. Mol. Sci. 2021, 22, 7634. [CrossRef] [PubMed]

20. Töpfer, E.; Boraschi, D.; Italiani, P. Innate Immune Memory: The Latest Frontier of Adjuvanticity. J. Immunol. Res. 2015, 2015, 478408. [CrossRef]

21. Valavanidis, A.; Vlachogianni, T.; Fiotakis, K. Tobacco smoke: Involvement of reactive oxygen species and stable free radicals in mechanisms of oxidative damage, carcinogenesis and synergistic effects with other respirable particles. Int. J. Environ. Res. Public Health 2009, 6, 445-462. [CrossRef] [PubMed]

22. Bals, R.; Hiemstra, P.S. Innate immunity in the lung: How epithelial cells fight against respiratory pathogens. Eur. Respir. J. 2004, 23, 327-333. [CrossRef] [PubMed]

23. Parker, D.; Prince, A. Innate immunity in the respiratory epithelium. Am. J. Respir. Cell Mol. Biol. 2011, 45, 189-201. [CrossRef] [PubMed]

24. Johnston, S.L.; Goldblatt, D.L.; Evans, S.E.; Tuvim, M.J.; Dickey, B.F. Airway Epithelial Innate Immunity. Front. Physiol. 2021, 12, 749077. [CrossRef]

25. Knowles, M.R.; Boucher, R.C. Mucus clearance as a primary innate defense mechanism for mammalian airways. J. Clin. Investig. 2002, 109, 571-577. [CrossRef]

26. Hariri, B.M.; Cohen, N.A. New insights into upper airway innate immunity. Am. J. Rhinol. Allergy 2016, 30, 319-323. [CrossRef] [PubMed]

27. Fahy, J.V.; Dickey, B.F. Airway mucus function and dysfunction. N. Engl. J. Med. 2010, 363, 2233-2247. [CrossRef]

28. Hiemstra, P.S. Antimicrobial peptides in the real world: Implications for cystic fibrosis. Eur. Respir. J. 2007, 29, 617-618. [CrossRef] [PubMed]

29. Thornton, D.J.; Rousseau, K.; McGuckin, M.A. Structure and function of the polymeric mucins in airways mucus. Annu. Rev. Physiol. 2008, 70, 459-486. [CrossRef]

30. Rose, M.C.; Voynow, J.A. Respiratory tract mucin genes and mucin glycoproteins in health and disease. Physiol. Rev. 2006, 86, 245-278. [CrossRef]

31. Li, J.; Ye, Z. The Potential Role and Regulatory Mechanisms of MUC5AC in Chronic Obstructive Pulmonary Disease. Molecules 2020, 25, 4437. [CrossRef]

32. Saco, T.V.; Breitzig, M.T.; Lockey, R.F.; Kolliputi, N. Epigenetics of Mucus Hypersecretion in Chronic Respiratory Diseases. Am. J. Respir. Cell Mol. Biol. 2018, 58, 299-309. [CrossRef]

33. Buisine, M.P.; Devisme, L.; Copin, M.C.; Durand-Réville, M.; Gosselin, B.; Aubert, J.P.; Porchet, N. Developmental mucin gene expression in the human respiratory tract. Am. J. Respir. Cell Mol. Biol. 1999, 20, 209-218. [CrossRef] [PubMed]

34. Radicioni, G.; Ceppe, A.; Ford, A.A.; Alexis, N.E.; Barr, R.G.; Bleecker, E.R.; Christenson, S.A.; Cooper, C.B.; Han, M.K.; Hansel, N.N.; et al. Airway mucin MUC5AC and MUC5B concentrations and the initiation and progression of chronic obstructive pulmonary disease: An analysis of the SPIROMICS cohort. Lancet Respir. Med. 2021, 9, 1241-1254. [CrossRef]

35. Leopold, P.L.; O'Mahony, M.J.; Lian, X.J.; Tilley, A.E.; Harvey, B.G.; Crystal, R.G. Smoking is associated with shortened airway cilia. PLoS ONE 2009, 4, e8157. [CrossRef] [PubMed]

36. Ganz, T. Defensins: Antimicrobial peptides of innate immunity. Nat. Rev. Immunol. 2003, 3, 710-720. [CrossRef]

37. Herr, C.; Beisswenger, C.; Hess, C.; Kandler, K.; Suttorp, N.; Welte, T.; Schroeder, J.-M.; Vogelmeier, C.; R Bals for the CAPNETZ Study Group. Suppression of pulmonary innate host defence in smokers. Thorax 2009, 64, 144-149. [CrossRef]

38. Bals, R.; Wang, X.; Wu, Z.; Freeman, T.; Bafna, V.; Zasloff, M.; Wilson, J.M. Human beta-defensin 2 is a salt-sensitive peptide antibiotic expressed in human lung. J. Clin. Investig. 1998, 102, 874-880. [CrossRef] [PubMed]

39. McCray, P.B., Jr.; Bentley, L. Human airway epithelia express a beta-defensin. Am. J. Respir. Cell Mol. Biol. 1997, 16, 343-349. [CrossRef] 
40. Feng, Z.; Jiang, B.; Chandra, J.; Ghannoum, M.; Nelson, S.; Weinberg, A. Human beta-defensins: Differential activity against candidal species and regulation by Candida albicans. J. Dent. Res. 2005, 84, 445-450. [CrossRef] [PubMed]

41. Wilson, S.S.; Wiens, M.E.; Smith, J.G. Antiviral mechanisms of human defensins. J. Mol. Biol. 2013, 425, 4965-4980. [CrossRef]

42. Proud, D.; Sanders, S.P.; Wiehler, S. Human rhinovirus infection induces airway epithelial cell production of human beta-defensin 2 both in vitro and in vivo. J. Immunol. 2004, 172, 4637-4645. [CrossRef] [PubMed]

43. Harder, J.; Meyer-Hoffert, U.; Teran, L.M.; Schwichtenberg, L.; Bartels, J.; Maune, S.; Schröder, J.M. Mucoid Pseudomonas aeruginosa, TNF-alpha, and IL-1beta, but not IL-6, induce human beta-defensin-2 in respiratory epithelia. Am. J. Respir. Cell Mol. Biol. 2000, 22, 714-721. [CrossRef] [PubMed]

44. Baines, K.J.; Wright, T.K.; Simpson, J.L.; McDonald, V.M.; Wood, L.G.; Parsons, K.S.; Wark, P.A.; Gibson, P.G. Airway $\beta$-Defensin-1 Protein Is Elevated in COPD and Severe Asthma. Mediators Inflamm. 2015, 2015, 407271. [CrossRef]

45. Cane, J.; Tregidgo, L.; Thulborn, S.; Finch, D.; Bafadhel, M. Antimicrobial Peptides SLPI and Beta Defensin-1 in Sputum are Negatively Correlated with FEV(1). Int. J. Chronic Obstr. Pulm. Dis. 2021, 16, 1437-1447. [CrossRef]

46. Liao, Z.; Dong, J.; Hu, X.; Wang, T.; Wan, C.; Li, X.o.; Li, L.; Guo, L.; Xu, D.; Wen, F. Enhanced expression of human $\beta$-defensin 2 in peripheral lungs of patients with chronic obstructive pulmonary disease. Peptides 2012, 38, 350-356. [CrossRef] [PubMed]

47. Turner, J.; Cho, Y.; Dinh, N.N.; Waring, A.J.; Lehrer, R.I. Activities of LL-37, a cathelin-associated antimicrobial peptide of human neutrophils. Antimicrob. Agents Chemother. 1998, 42, 2206-2214. [CrossRef] [PubMed]

48. Frohm, M.; Agerberth, B.; Ahangari, G.; Stâhle-Bäckdahl, M.; Lidén, S.; Wigzell, H.; Gudmundsson, G.H. The expression of the gene coding for the antibacterial peptide LL-37 is induced in human keratinocytes during inflammatory disorders. J. Biol. Chem. 1997, 272, 15258-15263. [CrossRef]

49. Bals, R.; Weiner, D.J.; Moscioni, A.D.; Meegalla, R.L.; Wilson, J.M. Augmentation of innate host defense by expression of a cathelicidin antimicrobial peptide. Infect. Immun. 1999, 67, 6084-6089. [CrossRef] [PubMed]

50. Jiang, Y.-Y.; Xiao, W.; Zhu, M.-X.; Yang, Z.-H.; Pan, X.-J.; Zhang, Y.; Sun, C.-C.; Xing, Y. The effect of human antibacterial peptide LL-37 in the pathogenesis of chronic obstructive pulmonary disease. Respir. Med. 2012, 106, 1680-1689. [CrossRef]

51. De Smet, K.; Contreras, R. Human Antimicrobial Peptides: Defensins, Cathelicidins and Histatins. Biotechnol. Lett. 2005, 27, 1337-1347. [CrossRef] [PubMed]

52. Scott, M.G.; Davidson, D.J.; Gold, M.R.; Bowdish, D.; Hancock, R.E.W. The Human Antimicrobial Peptide LL-37 Is a Multifunctional Modulator of Innate Immune Responses. J. Immunol. 2002, 169, 3883-3891. [CrossRef]

53. Kuroda, K.; Okumura, K.; Isogai, H.; Isogai, E. The Human Cathelicidin Antimicrobial Peptide LL-37 and Mimics are Potential Anticancer Drugs. Front. Oncol. 2015, 5, 144. [CrossRef]

54. Jiang, W.; Sunkara, L.T.; Zeng, X.; Deng, Z.; Myers, S.M.; Zhang, G. Differential regulation of human cathelicidin LL-37 by free fatty acids and their analogs. Peptides 2013, 50, 129-138. [CrossRef]

55. Schauber, J.; Iffland, K.; Frisch, S.; Kudlich, T.; Schmausser, B.; Eck, M.; Menzel, T.; Gostner, A.; Lührs, H.; Scheppach, W. Histone-deacetylase inhibitors induce the cathelicidin LL-37 in gastrointestinal cells. Mol. Immunol. 2004, 41, 847-854. [CrossRef] [PubMed]

56. Jiao, D.; Wong, C.-K.; Tsang, M.S.-M.; Chu, I.M.-T.; Liu, D.; Zhu, J.; Chu, M.; Lam, C.W.-K. Activation of Eosinophils Interacting with Bronchial Epithelial Cells by Antimicrobial Peptide LL-37: Implications in Allergic Asthma. Sci. Rep. 2017, 7, 1848. [CrossRef]

57. Zhang, Y.; Zhu, M.; Yang, Z.; Pan, X.; Jiang, Y.; Sun, C.; Wang, Q.; Xiao, W. The human Cathelicidin LL-37 induces MUC5AC mucin production by airway epithelial cells via TACE-TGF- $\alpha$-EGFR pathway. Exp. Lung Res. 2014, 40, 333-342. [CrossRef] [PubMed]

58. Parameswaran, G.I.; Sethi, S.; Murphy, T.F. Effects of bacterial infection on airway antimicrobial peptides and proteins in COPD. Chest 2011, 140, 611-617. [CrossRef]

59. Yang, Y.-M.; Guo, Y.-F.; Zhang, H.-S.; Sun, T.-Y. Antimicrobial peptide LL-37 circulating levels in chronic obstructive pulmonary disease patients with high risk of frequent exacerbations. J. Thorac. Dis. 2015, 7, 740-745. [CrossRef]

60. Tatsuta, M.; Kan, O.K.; Ishii, Y.; Yamamoto, N.; Ogawa, T.; Fukuyama, S.; Ogawa, A.; Fujita, A.; Nakanishi, Y.; Matsumoto, K. Effects of cigarette smoke on barrier function and tight junction proteins in the bronchial epithelium: Protective role of cathelicidin LL-37. Respir. Res. 2019, 20, 251. [CrossRef]

61. Kotlyarov, S.; Kotlyarova, A. Anti-Inflammatory Function of Fatty Acids and Involvement of Their Metabolites in the Resolution of Inflammation in Chronic Obstructive Pulmonary Disease. Int. J. Mol. Sci. 2021, 22, 12803. [CrossRef] [PubMed]

62. Tanabe, T.; Shimokawaji, T.; Kanoh, S.; Rubin, B.K. Secretory phospholipases A2 are secreted from ciliated cells and increase mucin and eicosanoid secretion from goblet cells. Chest 2015, 147, 1599-1609. [CrossRef] [PubMed]

63. Buczynski, M.W.; Dumlao, D.S.; Dennis, E.A. Thematic Review Series: Proteomics. An integrated omics analysis of eicosanoid biology. J. Lipid Res. 2009, 50, 1015-1038. [CrossRef] [PubMed]

64. Jakiela, B.; Gielicz, A.; Plutecka, H.; Hubalewska, M.; Mastalerz, L.; Bochenek, G.; Soja, J.; Januszek, R.; Musial, J.; Sanak, M. Eicosanoid biosynthesis during mucociliary and mucous metaplastic differentiation of bronchial epithelial cells. Prostaglandins Other Lipid Mediat. 2013, 106, 116-123. [CrossRef] [PubMed]

65. Profita, M.; Sala, A.; Riccobono, L.; Pace, E.; Paternò, A.; Zarini, S.; Siena, L.; Mirabella, A.; Bonsignore, G.; Vignola, A.M. 15(S)-HETE modulates LTB4 production and neutrophil chemotaxis in chronic bronchitis. Am. J. Physiol. -Cell Physiol. 2000, 279, C1249-C1258. [CrossRef] [PubMed] 
66. Lai, C.K.W.; Polosa, R.; Holgate, S.T. Effect of 15-(s)-Hydroxyeicosatetraenoic Acid on Allergen-induced Asthmatic Responses. Am. Rev. Respir. Dis. 1990, 141, 1423-1427. [CrossRef] [PubMed]

67. Nieves, D.; Moreno, J.J. Enantioselective effect of 12(S)-hydroxyeicosatetraenoic acid on 3T6 fibroblast growth through ERK 1/2 and p38 MAPK pathways and cyclin D1 activation. Biochem. Pharmacol. 2008, 76, 654-661. [CrossRef]

68. Chavis, C.; Godard, P.; Crastes de Paulet, A.; Damon, M. Formation of lipoxins and leukotrienes by human alveolar macrophages incubated with 15(S)-HETE: A model for cellular cooperation between macrophages and airway epithelial cells. Eicosanoids 1992, 5, 203-211.

69. Markovič, T.; Jakopin, Ž.; Dolenc, M.S.; Mlinarič-Raščan, I. Structural features of subtype-selective EP receptor modulators. Drug Discov. Today 2017, 22, 57-71. [CrossRef]

70. Sastre, B.; del Pozo, V. Role of PGE2 in asthma and nonasthmatic eosinophilic bronchitis. Mediat. Inflamm. 2012, $2012,645383$. [CrossRef]

71. Pavord, I.D.; Tattersfield, A.E. Bronchoprotective role for endogenous prostaglandin E2. Lancet 1995, 345, 436-438. [CrossRef]

72. Gauvreau, G.M.; Watson, R.M.; O'Byrne, P.M. Protective effects of inhaled PGE2 on allergen-induced airway responses and airway inflammation. Am. J. Respir. Crit. Care Med. 1999, 159, 31-36. [CrossRef] [PubMed]

73. Birrell, M.A.; Maher, S.A.; Dekkak, B.; Jones, V.; Wong, S.; Brook, P.; Belvisi, M.G. Anti-inflammatory effects of PGE ${ }^{2}$ in the lung: Role of the $\mathrm{EP}^{4}$ receptor subtype. Thorax 2015, 70, 740-747. [CrossRef]

74. Vancheri, C.; Mastruzzo, C.; Sortino, M.A.; Crimi, N. The lung as a privileged site for the beneficial actions of PGE ${ }^{2}$. Trends Immunol. 2004, 25, 40-46. [CrossRef]

75. van der Pouw Kraan, T.C.; Boeije, L.C.; Smeenk, R.J.; Wijdenes, J.; Aarden, L.A. Prostaglandin-E2 is a potent inhibitor of human interleukin 12 production. J. Exp. Med. 1995, 181, 775-779. [CrossRef] [PubMed]

76. Standiford, T.J.; Kunkel, S.L.; Rolfe, M.W.; Evanoff, H.L.; Allen, R.M.; Strieter, R.M. Regulation of human alveolar macrophageand blood monocyte-derived interleukin-8 by prostaglandin E2 and dexamethasone. Am. J. Respir. Cell Mol. Biol. 1992, 6, 75-81. [CrossRef]

77. Lazzeri, N.; Belvisi, M.G.; Patel, H.J.; Yacoub, M.H.; Chung, K.F.; Mitchell, J.A. Effects of prostaglandin E2 and cAMP elevating drugs on GM-CSF release by cultured human airway smooth muscle cells. Relevance to asthma therapy. Am. J. Respir. Cell Mol. Biol. 2001, 24, 44-48. [CrossRef]

78. N'Guessan, P.D.; Temmesfeld-Wollbrück, B.; Zahlten, J.; Eitel, J.; Zabel, S.; Schmeck, B.; Opitz, B.; Hippenstiel, S.; Suttorp, N.; Slevogt, H. Moraxella catarrhalis induces ERK- and NF-кB-dependent COX-2 and prostaglandin $\mathrm{E}^{2}$ in lung epithelium. Eur. Respir. J. 2007, 30, 443-451. [CrossRef]

79. Xu, F.; Xu, Z.; Zhang, R.; Wu, Z.; Lim, J.-H.; Koga, T.; Li, J.-D.; Shen, H. Nontypeable Haemophilus influenzae induces COX-2 and PGE2 expression in lung epithelial cells via activation of p38 MAPK and NF-kappa B. Respir. Res. 2008, 9, 16. [CrossRef] [PubMed]

80. N'Guessan, P.D.; Hippenstiel, S.; Etouem, M.O.; Zahlten, J.; Beermann, W.; Lindner, D.; Opitz, B.; Witzenrath, M.; Rosseau, S.; Suttorp, N.; et al. Streptococcus pneumoniae induced p38 MAPK- and NF-kB-dependent COX-2 expression in human lung epithelium. Am. J. Physiol. -Lung Cell. Mol. Physiol. 2006, 290, L1131-L1138. [CrossRef]

81. Montuschi, P.; Kharitonov, S.A.; Ciabattoni, G.; Barnes, P.J. Exhaled leukotrienes and prostaglandins in COPD. Thorax 2003, 58, 585-588. [CrossRef]

82. De Keijzer, S.; Meddens, M.B.M.; Torensma, R.; Cambi, A. The Multiple Faces of Prostaglandin E2 G-Protein Coupled Receptor Signaling during the Dendritic Cell Life Cycle. Int. J. Mol. Sci. 2013, 14, 6542-6555. [CrossRef]

83. Bayarri, M.A.; Milara, J.; Estornut, C.; Cortijo, J. Nitric Oxide System and Bronchial Epithelium: More Than a Barrier. Front. Physiol. 2021, 12, 687381. [CrossRef] [PubMed]

84. Kotlyarov, S. Diversity of Lipid Function in Atherogenesis: A Focus on Endothelial Mechanobiology. Int. J. Mol. Sci. 2021, 22, 11545. [CrossRef]

85. Lane, C.; Knight, D.; Burgess, S.; Franklin, P.; Horak, F.; Legg, J.; Moeller, A.; Stick, S. Epithelial inducible nitric oxide synthase activity is the major determinant of nitric oxide concentration in exhaled breath. Thorax 2004, 59, 757-760. [CrossRef]

86. Mattila, J.T.; Thomas, A.C. Nitric Oxide Synthase: Non-Canonical Expression Patterns. Front. Immunol. 2014, 5. [CrossRef]

87. Li, D.; Shirakami, G.; Zhan, X.; Johns, R.A. Regulation of ciliary beat frequency by the nitric oxide-cyclic guanosine monophosphate signaling pathway in rat airway epithelial cells. Am. J. Respir. Cell Mol. Biol. 2000, 23, 175-181. [CrossRef]

88. Hardiman, K.M.; McNicholas-Bevensee, C.M.; Fortenberry, J.; Myles, C.T.; Malik, B.; Eaton, D.C.; Matalon, S. Regulation of amiloride-sensitive $\mathrm{Na}(+)$ transport by basal nitric oxide. Am. J. Respir. Cell Mol. Biol. 2004, 30, 720-728. [CrossRef]

89. Olson, N.; Greul, A.K.; Hristova, M.; Bove, P.F.; Kasahara, D.I.; van der Vliet, A. Nitric oxide and airway epithelial barrier function: Regulation of tight junction proteins and epithelial permeability. Arch. Biochem. Biophys. 2009, 484, 205-213. [CrossRef] [PubMed]

90. Bogdan, C. Nitric oxide and the immune response. Nat. Immunol. 2001, 2, 907-916. [CrossRef] [PubMed]

91. MacMicking, J.; Xie, Q.-W.; Nathan, C. Nitric oxide and macrophage function. Annu. Rev. Immunol. 1997, 15, 323-350. [CrossRef]

92. Wink, D.A.; Hines, H.B.; Cheng, R.Y.S.; Switzer, C.H.; Flores-Santana, W.; Vitek, M.P.; Ridnour, L.A.; Colton, C.A. Nitric oxide and redox mechanisms in the immune response. J. Leukoc. Biol. 2011, 89, 873-891. [CrossRef]

93. Flak, T.A.; Goldman, W.E. Autotoxicity of nitric oxide in airway disease. Am. J. Respir. Crit. Care Med. 1996, 154, S202-S206. [CrossRef] [PubMed] 
94. Meng, Q.H.; Springall, D.R.; Bishop, A.E.; Morgan, K.; Evans, T.J.; Habib, S.; Gruenert, D.C.; Gyi, K.M.; Hodson, M.E.; Yacoub, M.H.; et al. Lack of inducible nitric oxide synthase in bronchial epithelium: A possible mechanism of susceptibility to infection in cystic fibrosis. J. Pathol. 1998, 184, 323-331. [CrossRef]

95. Robbins, R.A.; Barnes, P.J.; Springall, D.R.; Warren, J.B.; Kwon, O.J.; Buttery, L.D.; Wilson, A.J.; Geller, D.A.; Polak, J.M. Expression of inducible nitric oxide in human lung epithelial cells. Biochem. Biophys. Res. Commun. 1994, 203, 209-218. [CrossRef]

96. Asano, K.; Chee, C.B.; Gaston, B.; Lilly, C.M.; Gerard, C.; Drazen, J.M.; Stamler, J.S. Constitutive and inducible nitric oxide synthase gene expression, regulation, and activity in human lung epithelial cells. Proc. Natl. Acad. Sci. USA 1994, 91, 10089-10093. [CrossRef]

97. Jiang, W.-T.; Liu, X.-S.; Xu, Y.-J.; Ni, W.; Chen, S.-X. Expression of Nitric Oxide Synthase Isoenzyme in Lung Tissue of Smokers with and without Chronic Obstructive Pulmonary Disease. Chin. Med. J. 2015, 128, 1584-1589. [CrossRef]

98. Mio, T.; Romberger, D.J.; Thompson, A.B.; Robbins, R.A.; Heires, A.; Rennard, S.I. Cigarette smoke induces interleukin-8 release from human bronchial epithelial cells. Am. J. Respir. Crit. Care Med. 1997, 155, 1770-1776. [CrossRef] [PubMed]

99. Hellermann, G.R.; Nagy, S.B.; Kong, X.; Lockey, R.F.; Mohapatra, S.S. Mechanism of cigarette smoke condensate-induced acute inflammatory response in human bronchial epithelial cells. Respir. Res. 2002, 3, 22. [CrossRef]

100. Ma, W.-J.; Sun, Y.-H.; Jiang, J.-X.; Dong, X.-W.; Zhou, J.-Y.; Xie, Q.-M. Epoxyeicosatrienoic acids attenuate cigarette smoke extract-induced interleukin-8 production in bronchial epithelial cells. Prostaglandins Leukot. Essent. Fat. Acids 2015, 94, 13-19. [CrossRef]

101. Keatings, V.M.; Collins, P.D.; Scott, D.M.; Barnes, P.J. Differences in interleukin-8 and tumor necrosis factor-alpha in induced sputum from patients with chronic obstructive pulmonary disease or asthma. Am. J. Respir. Crit. Care Med. 1996, 153, 530-534. [CrossRef] [PubMed]

102. Janeway, C.A., Jr.; Medzhitov, R. Innate immune recognition. Annu. Rev. Immunol. 2002, 20, 197-216. [CrossRef]

103. Mayer, A.K.; Muehmer, M.; Mages, J.; Gueinzius, K.; Hess, C.; Heeg, K.; Bals, R.; Lang, R.; Dalpke, A.H. Differential Recognition of TLR-Dependent Microbial Ligands in Human Bronchial Epithelial Cells. J. Immunol. 2007, 178, 3134-3142. [CrossRef]

104. de C Ventura, G.M.; Le Goffic, R.; Balloy, V.; Plotkowski, M.-C.; Chignard, M.; Si-Tahar, M. TLR 5, but neither TLR2 nor TLR4, is involved in lung epithelial cell response to Burkholderia cenocepacia. FEMS Immunol. Med. Microbiol. 2008, 54, 37-44. [CrossRef]

105. Go, H.; Koh, J.; Kim, H.S.; Jeon, Y.K.; Chung, D.H. Expression of toll-like receptor 2 and 4 is increased in the respiratory epithelial cells of chronic idiopathic interstitial pneumonia patients. Respir. Med. 2014, 108, 783-792. [CrossRef]

106. Kawasaki, T.; Kawai, T. Toll-Like Receptor Signaling Pathways. Front. Immunol. 2014, 5, 461. [CrossRef]

107. MacRedmond, R.E.; Greene, C.M.; Dorscheid, D.R.; McElvaney, N.G.; O'Neill, S.J. Epithelial expression of TLR4 is modulated in COPD and by steroids, salmeterol and cigarette smoke. Respir. Res. 2007, 8, 84. [CrossRef]

108. Lee, S.W.; Kim, D.R.; Kim, T.J.; Paik, J.H.; Chung, J.-H.; Jheon, S.; Huh, J.W.; Lee, J.-H.; Lee, C.-T. The association of down-regulated toll-like receptor 4 expression with airflow limitation and emphysema in smokers. Respir. Res. 2012, 13, 106. [CrossRef] [PubMed]

109. Di Stefano, A.; Ricciardolo, F.L.M.; Caramori, G.; Adcock, I.M.; Chung, K.F.; Barnes, P.J.; Brun, P.; Leonardi, A.; Andò, F.; Vallese, D.; et al. Bronchial inflammation and bacterial load in stable COPD is associated with TLR4 overexpression. Eur. Respir. J. 2017, 49, 1602006. [CrossRef] [PubMed]

110. Chu, H.W.; Jeyaseelan, S.; Rino, J.G.; Voelker, D.R.; Wexler, R.B.; Campbell, K.; Harbeck, R.J.; Martin, R.J. TLR2 signaling is critical for Mycoplasma pneumoniae-induced airway mucin expression. J. Immunol. 2005, 174, 5713-5719. [CrossRef] [PubMed]

111. Kelly, D.; Conway, S. Bacterial modulation of mucosal innate immunity. Mol. Immunol. 2005, 42, 895-901. [CrossRef]

112. Abreu, M.T.; Vora, P.; Faure, E.; Thomas, L.S.; Arnold, E.T.; Arditi, M. Decreased Expression of Toll-Like Receptor-4 and MD-2 Correlates with Intestinal Epithelial Cell Protection against Dysregulated Proinflammatory Gene Expression in Response to Bacterial Lipopolysaccharide. J. Immunol. 2001, 167, 1609-1616. [CrossRef] [PubMed]

113. Sand, J.; Rønnow, S.R.; Langholm, L.; Karsdal, M.A.; Manon-Jensen, T.; Tal-Singer, R.; Miller, B.E.; Vestbo, J.; Leeming, D.J. A combination of biomarkers for fibrinolysis and basement membrane destruction predicts mortality in the ECLIPSE COPD cohort. Eur. Respir. J. 2020, 56, 4716. [CrossRef]

114. Kieliszek, M.; Lipinski, B. Pathophysiological significance of protein hydrophobic interactions: An emerging hypothesis. Med. Hypotheses 2018, 110, 15-22. [CrossRef]

115. Vlahos, R.; Bozinovski, S. Role of Alveolar Macrophages in Chronic Obstructive Pulmonary Disease. Front. Immunol. 2014, 5. [CrossRef] [PubMed]

116. Kapellos, T.S.; Bassler, K.; Aschenbrenner, A.C.; Fujii, W.; Schultze, J.L. Dysregulated Functions of Lung Macrophage Populations in COPD. J. Immunol. Res. 2018, 2018, 2349045. [CrossRef] [PubMed]

117. Tarling, J.D.; Lin, H.-S.; Hsu, S. Self-Renewal of Pulmonary Alveolar Macrophages: Evidence from Radiation Chimera Studies. J. Leukoc. Biol. 1987, 42, 443-446. [CrossRef]

118. SHAPIRO, S.D. The Macrophage in Chronic Obstructive Pulmonary Disease. Am. J. Respir. Crit. Care Med. 1999, 160, S29-S32. [CrossRef] [PubMed]

119. Pesci, A.; Balbi, B.; Majori, M.; Cacciani, G.; Bertacco, S.; Alciato, P.; Donner, C. Inflammatory cells and mediators in bronchial lavage of patients with chronic obstructive pulmonary disease. Eur. Respir. J. 1998, 12, 380-386. [CrossRef]

120. Di Stefano, A.; Capelli, A.; Lusuardi, M.; Balbo, P.; Vecchio, C.; Maestrelli, P.; Mapp, C.E.; Fabbri, L.M.; Donner, C.F.; Saetta, M. Severity of Airflow Limitation Is Associated with Severity of Airway Inflammation in Smokers. Am. J. Respir. Crit. Care Med. 1998, 158, 1277-1285. [CrossRef] 
121. Retamales, I.; Elliott, W.M.; Meshi, B.; Coxson, H.O.; Pare, P.D.; Sciurba, F.C.; Rogers, R.M.; Hayashi, S.; Hogg, J.C. Amplification of Inflammation in emphysema and Its Association with Latent Adenoviral Infection. Am. J. Respir. Crit. Care Med. 2001, 164, 469-473. [CrossRef]

122. Beckett, E.L.; Stevens, R.L.; Jarnicki, A.G.; Kim, R.Y.; Hanish, I.; Hansbro, N.G.; Deane, A.; Keely, S.; Horvat, J.C.; Yang, M.; et al. A new short-term mouse model of chronic obstructive pulmonary disease identifies a role for mast cell tryptase in pathogenesis. $J$. Allergy Clin. Immunol. 2013, 131, 752-762.e757. [CrossRef] [PubMed]

123. Mills, C.D.; Kincaid, K.; Alt, J.M.; Heilman, M.J.; Hill, A.M. M-1/M-2 macrophages and the Th1/Th2 paradigm. J. Immunol. 2000, 164, 6166-6173. [CrossRef]

124. Mantovani, A.; Sica, A.; Sozzani, S.; Allavena, P.; Vecchi, A.; Locati, M. The chemokine system in diverse forms of macrophage activation and polarization. Trends Immunol. 2004, 25, 677-686. [CrossRef]

125. Orecchioni, M.; Ghosheh, Y.; Pramod, A.B.; Ley, K. Macrophage Polarization: Different Gene Signatures in M1(LPS+) vs. Classically and M2(LPS-) vs. Alternatively Activated Macrophages. Front. Immunol. 2019, 10, 1084. [CrossRef]

126. Saqib, U.; Sarkar, S.; Suk, K.; Mohammad, O.; Baig, M.S.; Savai, R. Phytochemicals as modulators of M1-M2 macrophages in inflammation. Oncotarget 2018, 9, 17937-17950. [CrossRef] [PubMed]

127. Wang, N.; Liang, H.; Zen, K. Molecular mechanisms that influence the macrophage m1-m2 polarization balance. Front. Immunol. 2014, 5, 614. [CrossRef] [PubMed]

128. Viola, A.; Munari, F.; Sánchez-Rodríguez, R.; Scolaro, T.; Castegna, A. The Metabolic Signature of Macrophage Responses. Front. Immunol. 2019, 10, 1462. [CrossRef]

129. Brown, B.N.; Valentin, J.E.; Stewart-Akers, A.M.; McCabe, G.P.; Badylak, S.F. Macrophage phenotype and remodeling outcomes in response to biologic scaffolds with and without a cellular component. Biomaterials 2009, 30, 1482-1491. [CrossRef]

130. Italiani, P.; Boraschi, D. From Monocytes to M1/M2 Macrophages: Phenotypical vs. Functional Differentiation. Front. Immunol. 2014, 5, 514. [CrossRef]

131. Kumar, V. Macrophages: The Potent Immunoregulatory Innate Immune Cells. Macrophage Act. -Biol. Dis. 2019. [CrossRef]

132. Bazzan, E.; Turato, G.; Tinè, M.; Radu, C.M.; Balestro, E.; Rigobello, C.; Biondini, D.; Schiavon, M.; Lunardi, F.; Baraldo, S.; et al. Dual polarization of human alveolar macrophages progressively increases with smoking and COPD severity. Respir. Res. 2017, 18, 40. [CrossRef] [PubMed]

133. Hodge, S.; Hodge, G.; Ahern, J.; Jersmann, H.; Holmes, M.; Reynolds, P.N. Smoking alters alveolar macrophage recognition and phagocytic ability: Implications in chronic obstructive pulmonary disease. Am. J. Respir. Cell Mol. Biol. 2007, 37, 748-755. [CrossRef] [PubMed]

134. Berenson, C.S.; Kruzel, R.L.; Eberhardt, E.; Sethi, S. Phagocytic dysfunction of human alveolar macrophages and severity of chronic obstructive pulmonary disease. J. Infect. Dis. 2013, 208, 2036-2045. [CrossRef]

135. Han, C.Z.; Juncadella, I.J.; Kinchen, J.M.; Buckley, M.W.; Klibanov, A.L.; Dryden, K.; Onengut-Gumuscu, S.; Erdbrügger, U.; Turner, S.D.; Shim, Y.M.; et al. Macrophages redirect phagocytosis by non-professional phagocytes and influence inflammation. Nature 2016, 539, 570-574. [CrossRef]

136. Uribe-Querol, E.; Rosales, C. Phagocytosis: Our Current Understanding of a Universal Biological Process. Front. Immunol. 2020, 11. [CrossRef]

137. Aderem, A.; Underhill, D.M. Mechanisms of phagocytosis in macrophages. Annu. Rev. Immunol 1999, 17, 593-623. [CrossRef] [PubMed]

138. Grassin-Delyle, S.; Abrial, C.; Salvator, H.; Brollo, M.; Naline, E.; Devillier, P. The Role of Toll-Like Receptors in the Production of Cytokines by Human Lung Macrophages. J. Innate Immun. 2020, 12, 63-73. [CrossRef]

139. Karimi, K.; Sarir, H.; Mortaz, E.; Smit, J.J.; Hosseini, H.; De Kimpe, S.J.; Nijkamp, F.P.; Folkerts, G. Toll-like receptor-4 mediates cigarette smoke-induced cytokine production by human macrophages. Respir. Res. 2006, 7, 66. [CrossRef] [PubMed]

140. De Nardo, D.; De Nardo, C.M.; Latz, E. New insights into mechanisms controlling the NLRP3 inflammasome and its role in lung disease. Am. J. Pathol. 2014, 184, 42-54. [CrossRef]

141. Colarusso, C.; Terlizzi, M.; Molino, A.; Pinto, A.; Sorrentino, R. Role of the inflammasome in chronic obstructive pulmonary disease (COPD). Oncotarget 2017, 8, 81813-81824. [CrossRef]

142. Zhang, J.; Xu, Q.; Sun, W.; Zhou, X.; Fu, D.; Mao, L. New Insights into the Role of NLRP3 Inflammasome in Pathogenesis and Treatment of Chronic Obstructive Pulmonary Disease. J. Inflamm. Res. 2021, 14, 4155-4168. [CrossRef]

143. Faner, R.; Sobradillo, P.; Noguera, A.; Gomez, C.; Cruz, T.; López-Giraldo, A.; Ballester, E.; Soler, N.; Arostegui, J.I.; Pelegrín, P.; et al. The inflammasome pathway in stable COPD and acute exacerbations. ERJ Open Res. 2016, 2, 00002-02016. [CrossRef] [PubMed]

144. Wang, H.; Lv, C.e.; Wang, S.; Ying, H.; Weng, Y.; Yu, W. NLRP3 Inflammasome Involves in the Acute Exacerbation of Patients with Chronic Obstructive Pulmonary Disease. Inflammation 2018, 41, 1321-1333. [CrossRef]

145. Tran, H.B.; Lewis, M.D.; Tan, L.W.; Lester, S.E.; Baker, L.M.; Ng, J.; Hamilton-Bruce, M.A.; Hill, C.L.; Koblar, S.A.; Rischmueller, M.; et al. Immunolocalization of NLRP3 Inflammasome in Normal Murine Airway Epithelium and Changes following Induction of Ovalbumin-Induced Airway Inflammation. J. Allergy 2012, 2012, 819176. [CrossRef]

146. Nachmias, N.; Langier, S.; Brzezinski, R.Y.; Siterman, M.; Stark, M.; Etkin, S.; Avriel, A.; Schwarz, Y.; Shenhar-Tsarfaty, S.; Bar-Shai, A. NLRP3 inflammasome activity is upregulated in an in-vitro model of COPD exacerbation. PLoS ONE 2019, 14, e0214622. [CrossRef] 
147. Hassane, M.; Demon, D.; Soulard, D.; Fontaine, J.; Keller, L.E.; Patin, E.C.; Porte, R.; Prinz, I.; Ryffel, B.; Kadioglu, A.; et al. Neutrophilic NLRP3 inflammasome-dependent IL-1 $\beta$ secretion regulates the $\gamma \delta \mathrm{T} 17$ cell response in respiratory bacterial infections. Mucosal Immunol. 2017, 10, 1056-1068. [CrossRef]

148. Peiró, T.; Patel, D.F.; Akthar, S.; Gregory, L.G.; Pyle, C.J.; Harker, J.A.; Birrell, M.A.; Lloyd, C.M.; Snelgrove, R.J. Neutrophils drive alveolar macrophage IL-1 $\beta$ release during respiratory viral infection. Thorax 2018, 73, 546-556. [CrossRef]

149. Lea, S.R.; Reynolds, S.L.; Kaur, M.; Simpson, K.D.; Hall, S.R.; Hessel, E.M.; Singh, D. The effects of repeated Toll-like receptors 2 and 4 stimulation in COPD alveolar macrophages. Int. J. Chronic Obstr. Pulm. Dis. 2018, 13, 771-780. [CrossRef] [PubMed]

150. Soler, N.; Ewig, S.; Torres, A.; Filella, X.; Gonzalez, J.; Zaubet, A. Airway inflammation and bronchial microbial patterns in patients with stable chronic obstructive pulmonary disease. Eur. Respir. J. 1999, 14, 1015-1022. [CrossRef]

151. Foronjy, R.; Nkyimbeng, T.; Wallace, A.; Thankachen, J.; Okada, Y.; Lemaitre, V.; D'Armiento, J. Transgenic expression of matrix metalloproteinase-9 causes adult-onset emphysema in mice associated with the loss of alveolar elastin. Am. J. Physiol. -Lung Cell. Mol. Physiol. 2008, 294, L1149-L1157. [CrossRef]

152. Russell, R.E.K.; Thorley, A.; Culpitt, S.V.; Dodd, S.; Donnelly, L.E.; Demattos, C.; Fitzgerald, M.; Barnes, P.J. Alveolar macrophagemediated elastolysis: Roles of matrix metalloproteinases, cysteine, and serine proteases. Am. J. Physiol. -Lung Cell. Mol. Physiol. 2002, 283, L867-L873. [CrossRef]

153. Wallace, A.M.; Sandford, A.J.; English, J.C.; Burkett, K.M.; Li, H.; Finley, R.J.; Müller, N.L.; Coxson, H.O.; Paré, P.D.; Abboud, R.T. Matrix Metalloproteinase Expression by Human Alveolar Macrophages in Relation to Emphysema. COPD J. Chronic Obstr. Pulm. Dis. 2008, 5, 13-23. [CrossRef] [PubMed]

154. Finlay, G.A.; O’Driscoll, L.R.; Russell, K.J.; D'Arcy, E.M.; Masterson, J.B.; Fitzgerald, M.X.; O'Connor, C.M. Matrix Metalloproteinase Expression and Production by Alveolar Macrophages in Emphysema. Am. J. Respir. Crit. Care Med. 1997, 156, $240-247$. [CrossRef]

155. Kasahara, Y.; Tuder, R.M.; Cool, C.D.; Lynch, D.A.; Flores, S.C.; Voelkel, N.F. Endothelial cell death and decreased expression of vascular endothelial growth factor and vascular endothelial growth factor receptor 2 in emphysema. Am. J. Respir. Crit. Care Med. 2001, 163, 737-744. [CrossRef]

156. Konradt, C.; Hunter, C.A. Pathogen interactions with endothelial cells and the induction of innate and adaptive immunity. Eur. J. Immunol. 2018, 48, 1607-1620. [CrossRef]

157. Zhang, X.; Shan, P.; Jiang, G.; Cohn, L.; Lee, P.J. Toll-like receptor 4 deficiency causes pulmonary emphysema. J. Clin. Investig. 2006, 116, 3050-3059. [CrossRef] [PubMed]

158. Lacoste, J.Y.; Bousquet, J.; Chanez, P.; Van Vyve, T.; Simony-Lafontaine, J.; Lequeu, N.; Vic, P.; Enander, I.; Godard, P.; Michel, F.B. Eosinophilic and neutrophilic inflammation in asthma, chronic bronchitis, and chronic obstructive pulmonary disease. J. Allergy Clin. Immunol. 1993, 92, 537-548. [CrossRef]

159. Barnes, P.J. Inflammatory mechanisms in patients with chronic obstructive pulmonary disease. J. Allergy Clin. Immunol. 2016, 138, 16-27. [CrossRef] [PubMed]

160. Stănescu, D.; Sanna, A.; Veriter, C.; Kostianev, S.; Calcagni, P.G.; Fabbri, L.M.; Maestrelli, P. Airways obstruction, chronic expectoration, and rapid decline of FEV1 in smokers are associated with increased levels of sputum neutrophils. Thorax 1996, 51, 267-271. [CrossRef] [PubMed]

161. Fagon, J.Y.; Chastre, J.; Trouillet, J.L.; Domart, Y.; Dombret, M.C.; Bornet, M.; Gibert, C. Characterization of distal bronchial microflora during acute exacerbation of chronic bronchitis. Use of the protected specimen brush technique in 54 mechanically ventilated patients. Am. Rev. Respir. Dis. 1990, 142, 1004-1008. [CrossRef]

162. Jasper, A.E.; McIver, W.J.; Sapey, E.; Walton, G.M. Understanding the role of neutrophils in chronic inflammatory airway disease F1000Research 2019, 8, F1000 Faculty Rev-557. [CrossRef]

163. Donaldson, G.C.; Wedzicha, J.A. COPD exacerbations .1: Epidemiology. Thorax 2006, 61, 164-168. [CrossRef] [PubMed]

164. Traves, S.L.; Culpitt, S.V.; Russell, R.E.K.; Barnes, P.J.; Donnelly, L.E. Increased levels of the chemokines GRO $\alpha$ and MCP-1 in sputum samples from patients with COPD. Thorax 2002, 57, 590-595. [CrossRef] [PubMed]

165. Rovina, N.; Koutsoukou, A.; Koulouris, N.G. Inflammation and Immune Response in COPD: Where Do We Stand? Mediat. Inflamm. 2013, 2013, 413735. [CrossRef]

166. Knabe, L.; Petit, A.; Vernisse, C.; Charriot, J.; Pugnière, M.; Henriquet, C.; Sasorith, S.; Molinari, N.; Chanez, P.; Berthet, J.-P.; et al. CCSP counterbalances airway epithelial-driven neutrophilic chemotaxis. Eur. Respir. J. 2019, 54, 1802408. [CrossRef] [PubMed]

167. Hughes, M.J.; Sapey, E.; Stockley, R. Neutrophil phenotypes in chronic lung disease. Expert Rev. Respir. Med. 2019, 13, 951-967. [CrossRef]

168. Barnes, P.J.; Shapiro, S.D.; Pauwels, R.A. Chronic obstructive pulmonary disease: Molecular and cellularmechanisms. Eur. Respir. J. 2003, 22, 672-688. [CrossRef]

169. Janoff, A.; Scherer, J. Mediators of inflammation in leukocyte lysosomes. IX. Elastinolytic activity in granules of human polymorphonuclear leukocytes. J. Exp. Med. 1968, 128, 1137-1155. [CrossRef]

170. Kafienah, W.; Buttle, D.J.; Burnett, D.; Hollander, A.P. Cleavage of native type I collagen by human neutrophil elastase. Biochem. J. 1998, 330 Pt 2, 897-902. [CrossRef]

171. Finkelstein, R.; Fraser, R.S.; Ghezzo, H.; Cosio, M.G. Alveolar inflammation and its relation to emphysema in smokers. Am. J. Respir. Crit. Care Med. 1995, 152, 1666-1672. [CrossRef] 
172. Shaykhiev, R.; Crystal, R.G. Innate immunity and chronic obstructive pulmonary disease: A mini-review. Gerontology 2013, 59, 481-489. [CrossRef]

173. Banchereau, J.; Briere, F.; Caux, C.; Davoust, J.; Lebecque, S.; Liu, Y.J.; Pulendran, B.; Palucka, K. Immunobiology of dendritic cells. Annu. Rev. Immunol. 2000, 18, 767-811. [CrossRef]

174. Holt, P.G.; Stumbles, P.A. Regulation of immunologic homeostasis in peripheral tissues by dendritic cells: The respiratory tract as a paradigm. J. Allergy Clin. Immunol. 2000, 105, 421-429. [CrossRef] [PubMed]

175. Freeman, C.M.; Curtis, J.L. Lung Dendritic Cells: Shaping Immune Responses throughout Chronic Obstructive Pulmonary Disease Progression. Am. J. Respir. Cell Mol. Biol. 2017, 56, 152-159. [CrossRef] [PubMed]

176. Tsoumakidou, M.; Koutsopoulos, A.V.; Tzanakis, N.; Dambaki, K.; Tzortzaki, E.; Zakynthinos, S.; Jeffery, P.K.; Siafakas, N.M. Decreased small airway and alveolar CD83+ dendritic cells in COPD. Chest 2009, 136, 726-733. [CrossRef] [PubMed]

177. Rogers, A.V.; Adelroth, E.; Hattotuwa, K.; Dewar, A.; Jeffery, P.K. Bronchial mucosal dendritic cells in smokers and ex-smokers with COPD: An electron microscopic study. Thorax 2008, 63, 108-114. [CrossRef]

178. Divangahi, M.; Aaby, P.; Khader, S.A.; Barreiro, L.B.; Bekkering, S.; Chavakis, T.; van Crevel, R.; Curtis, N.; DiNardo, A.R.; Dominguez-Andres, J.; et al. Trained immunity, tolerance, priming and differentiation: Distinct immunological processes. Nat. Immunol. 2021, 22, 2-6. [CrossRef]

179. Cheng, S.-C.; Quintin, J.; Cramer, R.A.; Shepardson, K.M.; Saeed, S.; Kumar, V.; Giamarellos-Bourboulis, E.J.; Martens, J.H.A.; Rao, N.A.; Aghajanirefah, A.; et al. mTOR- and HIF- $1 \alpha$-mediated aerobic glycolysis as metabolic basis for trained immunity. Science 2014, 345, 1250684. [CrossRef]

180. Van Belleghem, J.D.; Bollyky, P.L. Macrophages and innate immune memory against Staphylococcus skin infections. Proc. Natl. Acad. Sci. USA 2018, 115, 11865-11867. [CrossRef]

181. Netea, M.G.; Joosten, L.A.B.; Latz, E.; Mills, K.H.G.; Natoli, G.; Stunnenberg, H.G.; O’Neill, L.A.J.; Xavier, R.J. Trained immunity: A program of innate immune memory in health and disease. Science 2016, 352, aaf1098. [CrossRef]

182. Netea, M.G.; Domínguez-Andrés, J.; Barreiro, L.B.; Chavakis, T.; Divangahi, M.; Fuchs, E.; Joosten, L.A.B.; van der Meer, J.W.M.; Mhlanga, M.M.; Mulder, W.J.M.; et al. Defining trained immunity and its role in health and disease. Nat. Rev. Immunol. 2020, 20, 375-388. [CrossRef]

183. Novakovic, B.; Habibi, E.; Wang, S.Y.; Arts, R.J.W.; Davar, R.; Megchelenbrink, W.; Kim, B.; Kuznetsova, T.; Kox, M.; Zwaag, J.; et al. $\beta$-Glucan Reverses the Epigenetic State of LPS-Induced Immunological Tolerance. Cell 2016, 167, 1354-1368.e1314. [CrossRef] [PubMed]

184. Yao, Y.; Jeyanathan, M.; Haddadi, S.; Barra, N.G.; Vaseghi-Shanjani, M.; Damjanovic, D.; Lai, R.; Afkhami, S.; Chen, Y.; Dvorkin-Gheva, A.; et al. Induction of Autonomous Memory Alveolar Macrophages Requires T Cell Help and Is Critical to Trained Immunity. Cell 2018, 175, 1634-1650.e1617. [CrossRef]

185. Zhong, C.; Yang, X.; Feng, Y.; Yu, J. Trained Immunity: An Underlying Driver of Inflammatory Atherosclerosis. Front. Immunol. 2020, 11, 284. [CrossRef] [PubMed]

186. Bekkering, S.; Quintin, J.; Joosten, L.A.B.; Meer, J.W.M.v.d.; Netea, M.G.; Riksen, N.P. Oxidized Low-Density Lipoprotein Induces Long-Term Proinflammatory Cytokine Production and Foam Cell Formation via Epigenetic Reprogramming of Monocytes. Arterioscler. Thromb. Vasc. Biol. 2014, 34, 1731-1738. [CrossRef]

187. Christ, A.; Günther, P.; Lauterbach, M.A.R.; Duewell, P.; Biswas, D.; Pelka, K.; Scholz, C.J.; Oosting, M.; Haendler, K.; Baßler, K.; et al. Western Diet Triggers NLRP3-Dependent Innate Immune Reprogramming. Cell 2018, 172, 162-175.e114. [CrossRef] [PubMed]

188. Norata, G.D. Trained immunity and cardiovascular disease: Is it time for translation to humans? Cardiovasc. Res. 2018, 114, e41-e42. [CrossRef]

189. Mehta, D.; Petes, C.; Gee, K.; Basta, S. The Role of Virus Infection in Deregulating the Cytokine Response to Secondary Bacterial Infection. J. Interferon Cytokine Res. 2015, 35, 925-934. [CrossRef] [PubMed] 